\title{
SPATIAL PATTERN IN BETA DIVERSITY OF ECHINOIDEA AND ASTEROIDEA COMMUNITIES FROM THE COASTAL AREA OF TOMIA ISLAND, WAKATOBI MARINE NATIONAL PARK, INDONESIA
}

\author{
KANGKUSO ANALUDDIN ${ }^{1,2^{*}}$, NASARUDD IN ${ }^{1}$, ANDI SEPTIANA ${ }^{1}$, WA ODE SARLIYANA ${ }^{1}$, \\ AG US NURLYATI ${ }^{1}$, WA MASA ${ }^{1}$ and SABAN RAHIM ${ }^{2}$ \\ ${ }^{1}$ Departmet of Bidoy, Faailty of Mathematics andNatural Saienes, \\ Halu OløUnivesity, Kendari 93232, Indonesia \\ ${ }^{2}$ TheMusamand Research Center of Wallace, Halu OleøUnivesity, \\ Kendari 93232, Indonesia
}

Received 15 D ecember 2013/ Accepted 16 January 2015

\begin{abstract}
ABST RACT
The purpose of this study was to elucidate the spatial pattern in the beta diversity of marine benthic Echinoidea and Asteroidea that inhabit the coastal area of Tomia Island, Wakatobi Marine National Park, Indonesia. Two transect lines of 460 and $260 \mathrm{~m}$ in length with small quadrats of $1 \mathrm{~m}^{2}$ were placed at the open and protected beaches perpendicularly to the coastlines. The importance value index and similarity index (SI) of organisms on these taxa were calculated along each transect. Edinomera mathae was the most dominant echinoid at open and protected beaches, while Protoresternodususwas the most dominant asteroid in both areas. Most SI values of Echinoidea at the open beach were estimated to be less than $50 \%$, which was lower than SI values of organisms at the protected beach. On the other hand, most of SI values of Asteroidea at both areas were estimated more than $70 \%$ reflecting high degree of similarity of its species composition among sites. The dissimilarity index of organisms in the taxa of Echinoidea and Asteroidea increased significantly with increasing distance between sites, which suggested that the pattern in betadiversity of these taxa was associated with spatial heterogeneity.
\end{abstract}

Keywords: Asteroidea, beta diversity, Echinoidea, Similarity Index, Wakatobi Marine National Park

\section{INTRODUCTION}

Nowadays, biodiversity of marine organisms is declining on global scale (G atson 2000; Roberts \& al. 2002), and therefore, more attention should be directed to conservation of marine biodiversity. Many scientists use the term beta diversity as a key component of biodiversity survey (G ray 2000). Beta diversity defined as the changes in composition of organisms or species diversity between habitats (Whittaker 1960). Beta diversity is known to provide useful information on marine area relationship or connectivity, which reflects the processes operating in those areas, and has been considered to be essential in environmental and conservation-based censuses and establishment of nature reserves (Purvis \&

\footnotetext{
* Corresponding author : zanzarafli@gmail.com
}

Hector 2000; Cleary 2003; Tuomitso \& al. 2003; Koleff $\notin$ al. 2003). Marine organisms play very important roles for stabilizing ecology of coastal ecosystem (Menge $\notin a l .1999)$, stabilizing inshore environments (Jie \& al. 2001), regulating atmospheric processes (Murphy \& D uffus 1996), providing food and pharmaceuticals for human (Hunt \& Vincent 2006), as well as functioning as recreational and aesthetic aspects (Ponder $\notin \mathrm{al}$. 2002). However, human activities such as overfishing (Jackson 2008), bottom trawling and dredging (Pauly \&al. 2005), as well as pollution of coastal waters (Halpern $\notin$ al. 2008) are known to have negative impact on benthic ecosystems sustainability.

Wakatobi Marine National Park often called an underwater paradise is among the world's most popular Marine Parks. This Marine Park has very high biodiversity resource potential, in terms of 
both species and uniqueness, and has become a leading tourist destination and focus of research activities. However, most studies in this region have been done for ecological assessment on coral reefs and fishes only, while few data are available regarding ecological organization for marine benthic Echinoidea and Asteroidea, which are fundamental for sustainable conservation of this Marine Park because of their significant role in the coastal food chain. These taxa also have high aesthetic value for tourism. Therefore, analyses of the spatial pattern in the beta diversity of these taxa may be useful for the potential ecotourism and conservation of biodiversity and the coastal environment of Wakatobi Marine National Park, Indonesia.

Echinoids are important food source for human. Daily exploitation of these organisms may threaten some species by over exploitation as well as habitat destruction. Most people living at the coastal area at the Wakatobi Marine National Park capture fish and also some species of marine benthic organisms. Therefore, understanding the spatial trends in beta diversity for Echinoidea and Asteroidea taxa may help to preserve their habitat and to ensure their future sustainability. Many ecologists realize that good understanding of the marine organisms in relation to environmental condition is essential to generate effective conservation schemes and guidelines for the sustainable exploitation of natural resources. In this effort determination of beta diversity of marine organisms plays an essential role ( $\mathrm{G}$ aston 2000; Lubchenco \&al. 2003; Tuomitso đal. 2003). Understanding the distribution and complexity of benthic habitats will provide important information for management goals (Kendall $\notin a \mathrm{al}$. 2005) and conservation strategy (Fortin $\&$ al. 2005), while identifying habitat characteristics for particular species are being increasingly taken up by marine ecologists to describe patterns of benthic diversity (Barrett \&al. 2001).

In the present study, the spatial pattern in the beta diversity of marine benthic organisms of Echinoidea and Asteroidea inhabiting the open and protected beaches of Tomia Island, Wakatobi
Marine National Park was elucidated. The spatial trend in abundance, similarity and dissimilarity indexes and ordination pattern of each taxon according to their distribution across the seashore gradient was described. The spatial patterns of beta diversity on these taxa were elucidated in relation to environmental conditions at open and protected beaches and distance from the beach. To know whether distance between sites or patches affects the similarity index in each taxon, the relationship between distance and disimilarity index among sites were analyzed. These analyses were performed by estimating interval ordination from randomly selected paired sites, and then generating regression model between interval ordination and dissimilarity index.

\section{MATERIALS AND METHODS}

\section{Study Site}

The present study was carried out along the coast of Tomia Island, Wakatobi Marine National Park located at the $5^{\circ} 46^{\prime} \mathrm{S}$ and $123^{\circ} 55^{\prime} \mathrm{E}$ of Southeast Sulawesi Province, Indonesia (Fig. 1).

The study was conducted in D ecember 2010. Meteorological data taken from Kendari station showed that annual temperature range was 24-33 ${ }^{\circ} \mathrm{C}$, while the minimum and maximum temperature during study period were $24{ }^{\circ} \mathrm{C}$ and $32{ }^{\circ} \mathrm{C}$, respectively. Annual rainfall was 2,000 $\mathrm{mm}$ at the mountain, while it was $200 \mathrm{~mm}$ at the coastal area. In addition, annual relative moisture ranged from $75 \%$ to $84 \%$, whereas relative moisture was $76 \%$ at the study period with six rainy days. The beach condition of Tomia Island provides an excellent site for ecological study of marine invertebrates. The beach provides a unique panorama as it is surrounded by some small islands, which protect the beach from heavy wave action of the Banda Sea, while other areas are exposed to direct heavy wave action. The substratum is composed of rock and sand. However, some species of seagrasses occur at the study site, such as Cymodbera roundata, Cymodberat senulata, Enhalusacorcidesand Halophilaminor. 


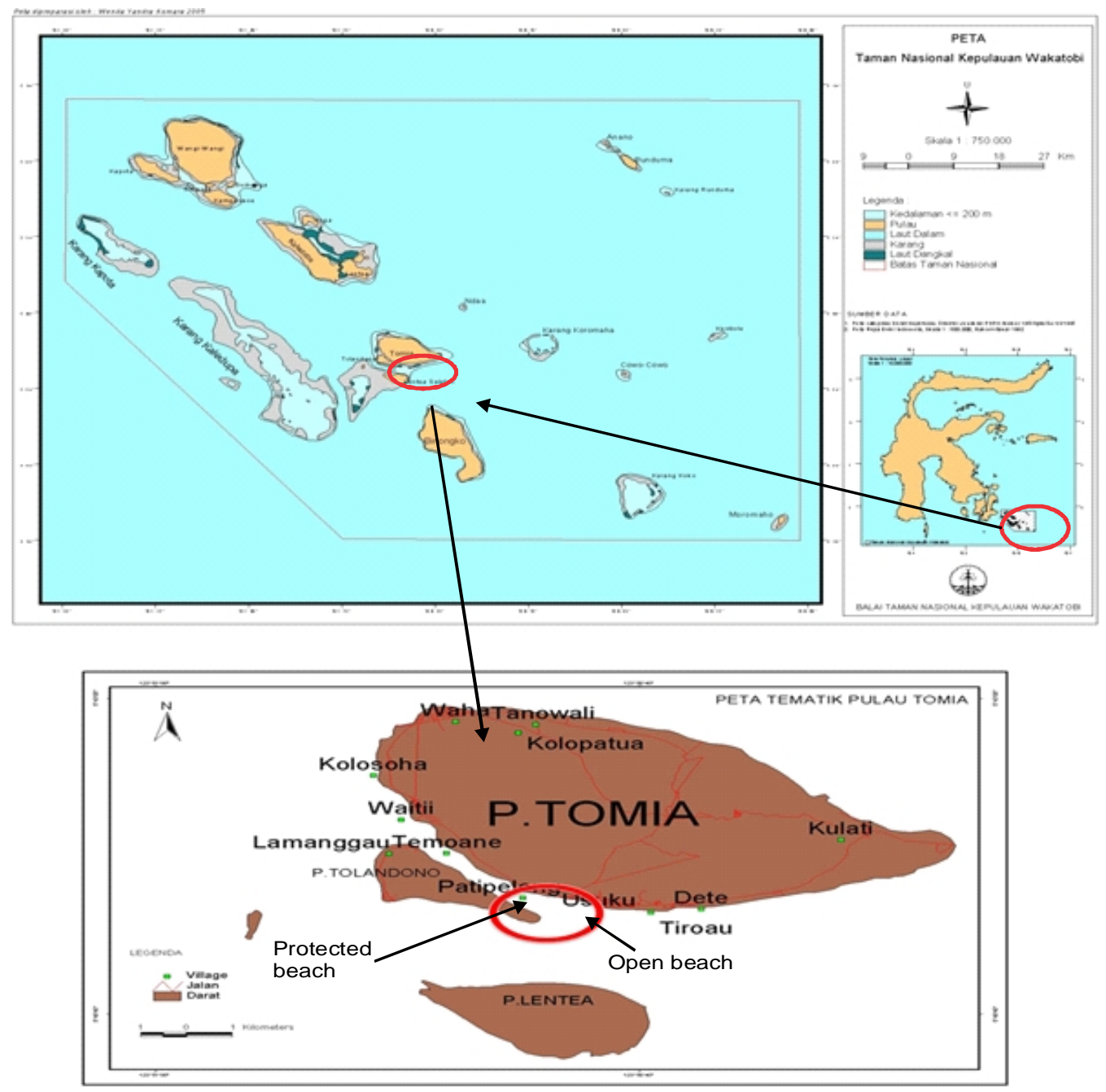

Figure 1. Study sites of open and protected beaches (circled) in the coastal areas of Tomia Island, Wakatobi Marine National Park, Indonesia

\section{Sampling Method}

The two transect lines were placed perpendicularly to the costal area of Tomia Island at the Wakatobi Marine National Park. Transect I with a length of $460 \mathrm{~m}$ was placed at open beach and divided into 13 sites or patches $\left(400 \mathrm{~m}^{2}\right.$ wide each), while transect II with length of $260 \mathrm{~m}$ was placed at protected beach and divided into 7 sites (400 $\mathrm{m}^{2}$ wide each). Furthermore, five small quadrats ( $1 \mathrm{~m}^{2}$ wide each) were placed purposively in each site both at open and protected beaches, respectively. The name of species and their individual numbers for Echinoidea and Asteroidea in each small quadrat were directly observed in the field using Shirai (1997), while unknown species was brought to the laboratory for identification. For determining the organic content, the sediment samples were taken from both transects and brought to the Laboratory of
Ecology and Taxonomy, Halu Oleo University, Kendari. The sediment samples were air-dried for seven days. Then $10 \mathrm{~g}$ of the air-dried sediment samples were taken and oven-dried at $105^{\circ} \mathrm{C}$ for 24 hours and weighed. The samples then dryashed at $700{ }^{\circ} \mathrm{C}$ for 2 hours and weighed. The percentage of organic matter content of sediment samples was estimated according to Brower \&al. (1997).

\section{Data Analysis}

The similarity and dissimilarity indexes of organisms among sites for Echinoidea and Asteroidea in both transects at open and protected beaches were calculated using formula of Bray and Curtis (1957). In addition, ordination analyses were applied for elucidation of the multidimensional pattern. The spatial pattern in the beta diversity of each taxon was elucidated in 
relation to the condition of open and protected beaches, distance from shore and substrate types of the beach. To know whether interval among sites affects the similarity index for each taxon, the relationship between distance among sites and dissimilarity index of each taxon were analyzed. These analyses were performed by estimating the interval ordination from randomly selected paired sites, and then generated regression model between the ordination and dissimilarity index for both taxa. The coefficient correlation of regression line was estimated, and a statistical test was done for determining whether there was any or no correlation between distance among sites and dissimilarity index for each taxon.

\section{RESULTS AND DISCUSSION}

The present study showed a little variation of organic matter content of sediment among habitats: 1) sandy areas with the seagrasses estimated at $14.62 \%$; 2) rocky habitat at $14.43 \%$; and 3) mixed rocky and sand habitat at $13.78 \%$. However, diversity of the marine benthic for Echinoid and Asteroid communities inhabited the coastal area of Tomia Island, Wakatobi Marine National Park varied at open and protected beaches. Nine species of Echinoids occurred on open beach, while eight species were found only at protected beach in the coastal area of Tomia Island (Table1).
Edhinameramathad was the dominant E chinoid both at open and protected beaches of Tomia Island, indicating its high important role for sustainability of coastal ecosystem. On the other hand, Diadama stosumwas the rarest Echinoid in this coastal area, which might be less adaptable with environmental condition (Fig. 2).

Meanwhile, few Asteroids species were found in this coastal area with only four species on both open and protected beaches (Table 2).

Protoreaster nodusus was the dominant Asteroid in both areas, while Ardhastertypiauswas the rarest Asteroid (Fig. 3). Differences in species compostion of marine benthic at present study might be determined by habitat characteristics and organic matter content. Beaman \& al. (2005) found that habitat characteristic affected marine benthic composition. Rocky reef habitats influenced the behavior of benthic organisms, and in turn influenced higher level processes of population dynamics and community structure (Knight \& Morris 1996). Sandy habitats are important for burrowing organisms and their predators and provide foraging areas for species which may also use nearby firm substrate areas for sheltering purposes (Ross $\&$ al. 2007). Therefore, spatial pattern in the community composition of Echinoidea and Asteroidea might be associated with substrate types at small patches in particular the coastal area of Tomia Island.

Table 1. Species composition of Echinoidea at open and protected beaches in the coastal area of Tomia Island, Wakatobi MarineNational Park, Indonesia

\begin{tabular}{|c|c|c|c|c|}
\hline No. & Family & Species & $\begin{array}{l}\text { Open beach } \\
\text { (Transect I) }\end{array}$ & $\begin{array}{l}\text { Protected beach } \\
\text { (Transect II) }\end{array}$ \\
\hline \multirow{4}{*}{1} & \multirow{4}{*}{ Echinometridae } & Edinostrephus aaialatus & $\sqrt{ }$ & $\sqrt{ }$ \\
\hline & & Edinamera mathae & $\sqrt{ }$ & $\sqrt{ }$ \\
\hline & & Edinometrasp. A & $\sqrt{ }$ & $\sqrt{ }$ \\
\hline & & Edinometrasp. B & $\sqrt{ }$ & $\sqrt{ }$ \\
\hline \multirow{2}{*}{2} & \multirow{2}{*}{ Temnopleuridae } & Salmacis sphaercides & $\sqrt{ }$ & - \\
\hline & & Temppleinusalexandni & $\sqrt{ }$ & $\sqrt{ }$ \\
\hline \multirow{3}{*}{3} & \multirow{3}{*}{ Diadematidae } & Astropyga radiate & - & - \\
\hline & & Diadama stosum & $\sqrt{ }$ & $\sqrt{ }$ \\
\hline & & Edinotrix calamanis & $\sqrt{ }$ & $\sqrt{ }$ \\
\hline \multirow{2}{*}{4} & \multirow{2}{*}{ Toxopneustidae } & Toxqpnenstespiliedus & - & - \\
\hline & & Tripnaustes gatilla & $\sqrt{ }$ & - \\
\hline 5 & Brissidae & Bissus lateraninatus & - & $\sqrt{ }$ \\
\hline
\end{tabular}

Notes : $\sqrt{ }$ (present), - (absent) 


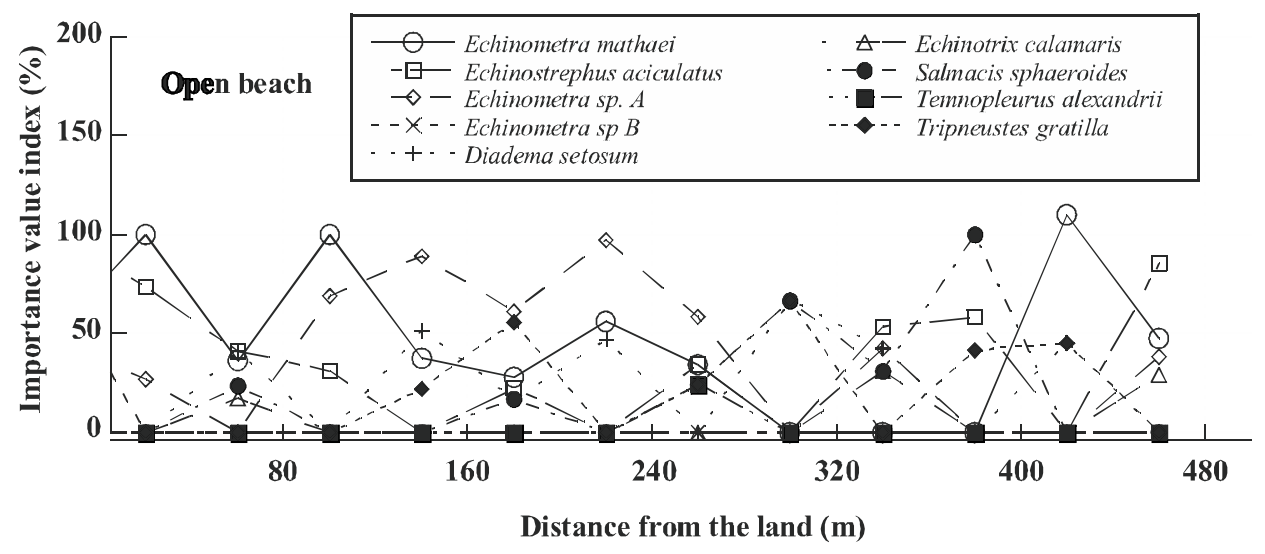

Protected beach

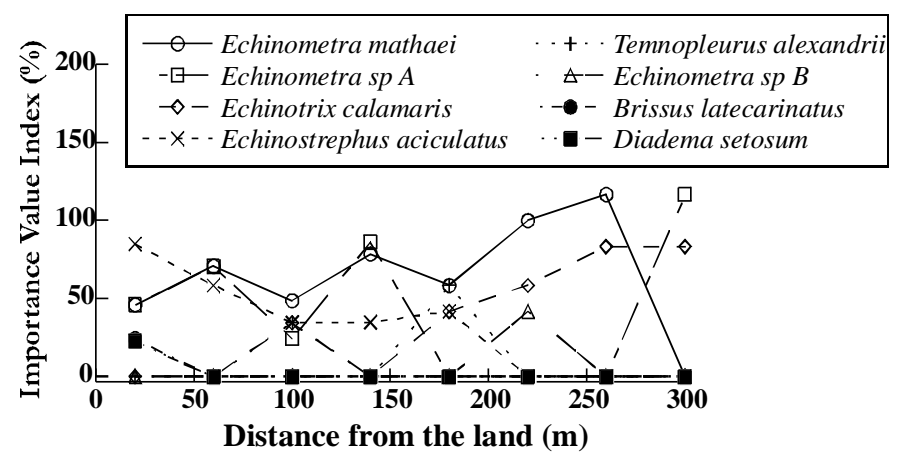

Figure 2. Spatial trends in the Importance Value Index (IVI) of E chinoidea community at open beach (upper) and protected beach (below) in the coastal area of Tomia Island, Wakatobi Marine National Park, Indonesia

Table2. Species composition of Asteroidea at open and protected beaches in the coastal area of Tomia Island, Wakatobi Marine National Park, Indonesia

\begin{tabular}{|c|c|c|c|c|}
\hline No. & Family & Species & $\begin{array}{l}\text { Open beach } \\
\text { (Transect I) }\end{array}$ & $\begin{array}{l}\text { Protected beach } \\
\text { (Transect II) }\end{array}$ \\
\hline \multirow{2}{*}{1} & \multirow{2}{*}{ O phidlasteridae } & Protaraster nodusus & $\sqrt{ }$ & $\sqrt{ }$ \\
\hline & & Lindkia laavigata & $\sqrt{ }$ & $\sqrt{ }$ \\
\hline 2 & O reasteridae & Culata noraeginge & $\sqrt{ }$ & - \\
\hline 3 & Archasteridae & Archaster typias & $\sqrt{ }$ & $\sqrt{ }$ \\
\hline 4 & Astropectenidae & Astrupeten scapanius & - & $\sqrt{ }$ \\
\hline
\end{tabular}

Notes: $\sqrt{ }$ (present), - (absent)

The similarity indexes of E chinoid community both at open and protected beaches are described in Tables 3 and 4, respectively.

As shown in Table 3 the similarity indexes of Echinoids varied among sites, while three values of Similarity Indexes (SI) were estimated more than $85 \%$, i.e. the SI values of paired sites I-II, VVII and of paired sites I-XII. However, twentythree SI values of paired sites of Echinoids were estimated more than $50 \%$, whilemore than half of the SI values of Echinoids were less than $50 \%$, even five SI values of paired sites were zero. These results suggested that there was a lower degree of similarity species of Echinoids among sites at open beaches of Tomia Island. O n the other hand, Table 4 shows that more than half of the SI values of Echinoids at protected beaches were estimated to be more than $50 \%$, indicating a high degree of similarity among sites for Echinoids at protected beaches, although two SI values were estimated as zero or completely different. These trends demonstrate the change in the Echinoids species composition across open beaches, which might be due to heavy wave action. There was only small change in species composition of Echinoids across protected beach from heavy wave action. 

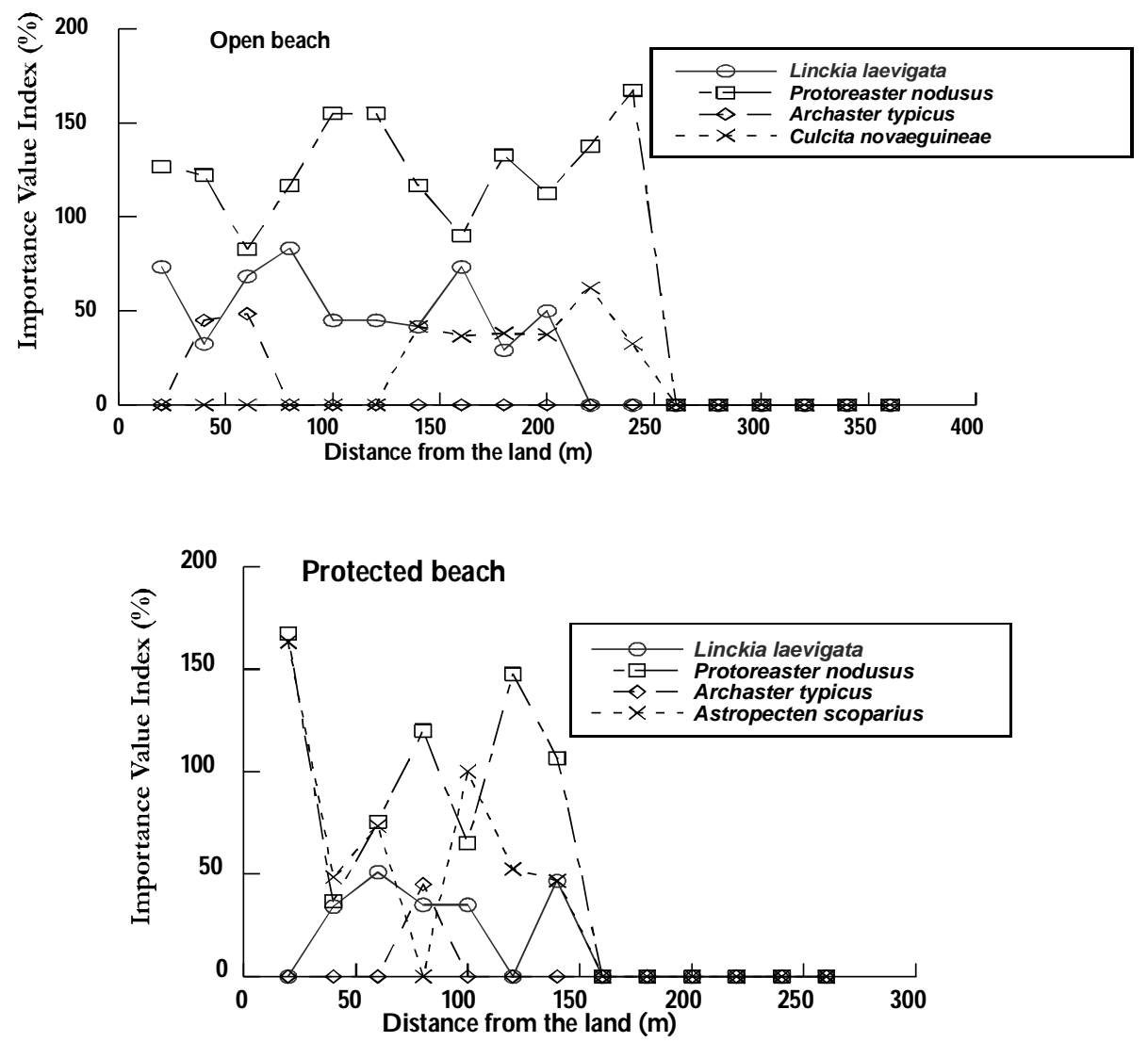

Figure 3. Spatial trends in the Importance Value Index (IVI) of Asteroidea community at open beach (upper) and protected beach (below) in the coastal area of Tomia Island, Wakatobi Marine National Park, Indonesia

Table3. Similarity and Dissimilarity Indexes of Echinoids at open beaches in the coastal area of Tomia Island, Wakatobi Marine National Park, Indonesia

\begin{tabular}{crccccccccccrr}
\hline SI\ D I & I & \multicolumn{1}{c}{ II } & \multicolumn{1}{c}{ III } & \multicolumn{1}{c}{ IV } & V & VI & VII & VIII & IX & X & XI & XII & XIII \\
\hline 1 & - & 12.5 & 61.46 & 28.27 & 62.57 & 56.25 & 53.33 & 46.96 & 100 & 54.58 & 70.83 & 62.5 & 14.89 \\
2 & 87.5 & - & 61.46 & 21.19 & 67.98 & 61.67 & 58.75 & 52.38 & 100 & 60 & 70.83 & 50 & 26.36 \\
3 & 38.55 & 38.54 & - & 66.47 & 61.46 & 58,33 & 61.46 & 53.91 & 67.71 & 38.55 & 67.71 & 61.46 & 52.78 \\
4 & 71.73 & 78.81 & 33.53 & - & 46.79 & 44.44 & 37.55 & 38.10 & 100 & 63.41 & 84.52 & 50 & 41.8 \\
5 & 37.43 & 32.05 & 38.54 & 53.20 & - & 36.23 & 13.44 & 42.58 & 63.19 & 57.78 & 89.01 & 47.83 & 62.23 \\
6 & 43.75 & 38.33 & 41.67 & 55.56 & 63.77 & - & 47.22 & 25.24 & 63.89 & 51.11 & 61.11 & 58.33 & 55.91 \\
7 & 46.67 & 41.25 & 38.55 & 62.45 & 86.56 & 52.78 & - & 53.57 & 76.62 & 57.78 & 100 & 49.58 & 57.27 \\
8 & 53.04 & 47.62 & 46.09 & 61.91 & 57.42 & 74.77 & 46.43 & - & 75.71 & 49.60 & 58.57 & 70.71 & 46.62 \\
9 & 0 & 0 & 32.29 & 0 & 36.81 & 36.11 & 23.38 & 24.29 & - & 63.33 & 45.83 & 55 & 100 \\
10 & 45.42 & 40 & 61.46 & 36.59 & 42.22 & 48.89 & 42.22 & 50.40 & 36.67 & - & 57.78 & 78.89 & 39.7 \\
11 & 29.17 & 29.17 & 32.29 & 15.48 & 10.99 & 38.89 & 0 & 41.43 & 54.17 & 42.22 & - & 79.17 & 70.83 \\
12 & 37.5 & 50 & 38.54 & 50 & 52.17 & 41.67 & 50,42 & 29.29 & 45 & 21.11 & 20.83 & - & 76.36 \\
13 & 85.11 & 73.65 & 47.22 & 58.20 & 37.77 & 44.09 & 42.73 & 53.38 & 0 & 60.30 & 29.17 & 23.65 & - \\
\hline
\end{tabular}


Table4. Similarity and Dissimilarity Indexes of Echinoids at protected beaches in the coastal area of Tomia Island, Wakatobi Marine National Park, Indonesia

\begin{tabular}{cllcccccc}
\hline SI $\backslash$ D I & I & II & III & IV & V & VI & VII & VIII \\
\hline 1 & - & 24.78 & 47.69 & 36.52 & 59,83 & 47.81 & 35.31 & 76.97 \\
2 & 75.22 & - & 46.43 & 11.74 & 58,57 & 35.42 & 35.42 & 64.58 \\
3 & 52.31 & 53.57 & - & 46.43 & 24,29 & 58.57 & 58.57 & 70.71 \\
4 & 63.48 & 88.26 & 53.57 & - & 58,57 & 43.18 & 43.18 & 58.33 \\
5 & 40.17 & 41.43 & 75.71 & 41.43 & - & 58.57 & 58.57 & 82.86 \\
6 & 52.19 & 64.58 & 41.43 & 56.82 & 41.43 & - & 20.83 & 100 \\
7 & 64.69 & 64.58 & 41.43 & 56.82 & 41.43 & 79.17 & - & 100 \\
8 & 23.03 & 35.42 & 29.29 & 41.67 & 17.14 & 0 & 0 & - \\
\hline
\end{tabular}

Table5. Similarity and Dissimilarity Indexes of Asteroids at open beaches in the coastal area of Tomia Island, Wakatobi Marine National Park, Indonesia

\begin{tabular}{ccccccccccccc}
\hline SI D I & I & II & III & IV & V & VI & VII & VIII & IX & X & XI & XII \\
\hline 1 & - & 22.5 & 24.28 & 34.16 & 14.16 & 14.16 & 20.83 & 18.33 & 22.12 & 18.75 & 36.66 & 36.67 \\
2 & 77.5 & - & 19.82 & 25.41 & 22.5 & 22.5 & 25.41 & 38.75 & 24.20 & 27.5 & 38.75 & 38.75 \\
3 & 75.71 & 80.17 & - & 7.38 & 36.07 & 36.07 & 37.73 & 24.28 & 44.02 & 33.57 & 33.57 & 38.75 \\
4 & 65.83 & 74.58 & 92.61 & - & 19.16 & 19.16 & 20.83 & 18.33 & 27.12 & 18.75 & 33.57 & 38.75 \\
5 & 85.83 & 77.5 & 63.92 & 80.83 & - & 19.16 & 20.83 & 18.33 & 27.12 & 18.75 & 41.66 & 41.67 \\
6 & 85.83 & 77.5 & 63.92 & 80.83 & 100 & - & 20.83 & 32.5 & 85.45 & 21.25 & 31.11 & 22.5 \\
7 & 79.16 & 74.58 & 62.26 & 79.16 & 79.16 & 79.16 & - & 32.5 & 19.09 & 21.25 & 31.11 & 22.5 \\
8 & 81.66 & 61.25 & 75.71 & 81.66 & 67.5 & 67.5 & 84.16 & - & 8.03 & 4.166 & 20.83 & 100 \\
9 & 77.87 & 75.79 & 55.97 & 72.87 & 14.54 & 80.90 & 91.96 & 77.87 & - & 11.66 & 14.54 & 38.75 \\
10 & 81.25 & 72.5 & 66.42 & 81.25 & 78.75 & 78.75 & 95.83 & 88.33 & 89.54 & - & 14.54 & 17.36 \\
11 & 63.33 & 61.25 & 66.42 & 58.33 & 68.88 & 68.88 & 79.16 & 63.33 & 85.45 & 75 & - & 27.5 \\
12 & 63.33 & 61.25 & 61.25 & 58.33 & 77.5 & 77.5 & 74.58 & 61.25 & 82.61 & 72.5 & 85.13 & - \\
\hline
\end{tabular}

Table 5 hows the Similarity Indexes (SI) for Asteroids at open beaches. The SI values of Asteroids were less variable with only a few SI values of Asteroids estimated to be less than $50 \%$, while many SI values were estimated to be more than $80 \%$, and even some SI values estimated to be nearly $100 \%$. These results indicated that there was high similarity of species composition of Asteroids at open beaches of Tomia Island. A similar trend in the SI values of Asteroids was found at protected beaches.

As is shown in Table 6 there only three SI values of Asteroids at protected beaches were estimated to be less than $50 \%$, while more than half of SI values of Asteroidea were estimated to be above $70 \%$, indicating the high degree of similarity in species of Asteroids at protected beaches of TomiaIsland.

Multidimensional patterns of the benthic community of Echinoids and Asteroids at the study site were elucidated by ordination analyses.
The ordination pattern of Echinoids at open beach (Fig. 4, upper) showed four groups: 1) Group A consisted of four sites or patches including sites I, II, IV and sites XIII; 2) Group $B$ consisted of five sites (sites III, VI, VIII, X and sites XII); 3) Group C consisted of sites V and VII; and 4) Group D consisted of sites IX and XI. The sites located at the same groups indicated that Echinoids species might have similar or matching resource requirement and environmental preferences. The ordination pattern of Echinoids along transect II or protected beaches (Fig. 4, below) could be also divided into 4 groups, though the sites in each group differed as compared to the ordination pattern of Echinoids at open beaches. These four groups were as follows: 1) Group A consisted of sites III and $V$;2) G roup B consisted of sites I, II, and IV; 3) Group C consisted of site VIII only; and 4) Group D included sites VI andVII. 
Table6. Similarity and D issimilarity Indexes of Asteroids at protected beaches in the coastal area of Tomia Island, Wakatobi Marine National Park, Indonesia

\begin{tabular}{cccccccc}
\hline SI $\backslash$ DI & 1 & 2 & 3 & 4 & 5 & 6 & 7 \\
\hline 1 & - & 57.38 & 45 & 40 & 31.66 & 55.53 & 58.33 \\
2 & 42.61 & - & 20.79 & 24.28 & 26.07 & 17.14 & 6.19 \\
3 & 55 & 79.20 & - & 44.72 & 36.08586 & 36.08 & 15.55 \\
4 & 60 & 75.71 & 55.27 & - & 50 & 40 & 29.16 \\
5 & 68.33 & 73.92 & 86.66 & 50 & - & 41.36 & 26.67 \\
6 & 44.46 & 82.85 & 63.91 & 60 & 58.63 & - & 23.33 \\
7 & 41.66 & 93.80 & 84.44 & 70.83 & 73.33 & 76.66 & - \\
\hline
\end{tabular}
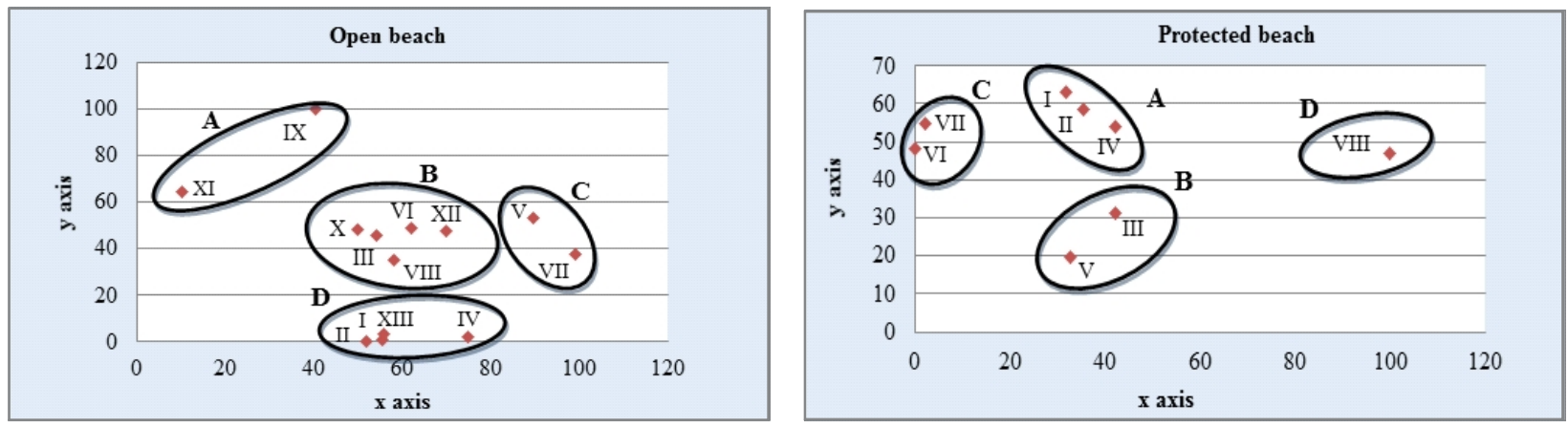

Figure 4. O rdination pattern of Echinoidea community at open beach (left) and protected beach (right) in the coastal area of Tomia Island, Wakatobi Marine National Park, Indonesia

Statistical analysis using regression model (Fig. 5) showed that the Dissimilarity Indexes (DI) of Echinoids among sites both at open and protected beaches increased significantly with increasing interval ordination or separation of sites or patches $(p<0.001)$. This means that the degree of similarity of Echinoids both at open and protected beaches decreased with increasing distanceamong sites.

The ordination pattern of asteroids on open beach (Fig. 6) could also divided into 4 group: (1) G roup A consisted of site XII only; (2) Group B consisted of sites III, IV, V, VI, VII, IX and site X I; (3) Group C included sites I and II; and (4) Group D consisted of site VIII only. The same ordination pattern of asteroids was found at the transect II (Figure 6), although the sites in esch froup were different as compared to the grouping in the transect I. These groups at transect II are: (1) Group A contained sites, II, IV and VI; (2) Group B consisted of site IV only; (3) G roup C contained site I only; and (4) Group D included sites III and V.

Statistical analysis using a regression model (Fig. 7) showed that D issimilarity Indexes (DI) of Asteroids among sites both at open and protected beaches also increased significantly with increasing interval ordination or separation of sites $(p<0.01)$. This means that the degree of similarity of Asteroids among sites at open and protected beaches decreased with increasing distance among sites both at open and protected beaches.

These spatial heterogeneities might be correlated to the environmental condition of the beach, such as substrate types and distance from the offshore. This happened because the Echinoids and Asteroids communites showed high similarity among sites in general both at open and protected beaches. The degree of similarity in some sites for both taxa were completely different although they responded to the same sets of substrate types, which might influence the community structure of marine benthic community in the Tomia Island.

The community composition of Echinoids and Asteroids in each site might be significantly associated with substrate types in small patches. For species that have limited dispersal abilities, distance or spatial component is expected to be 

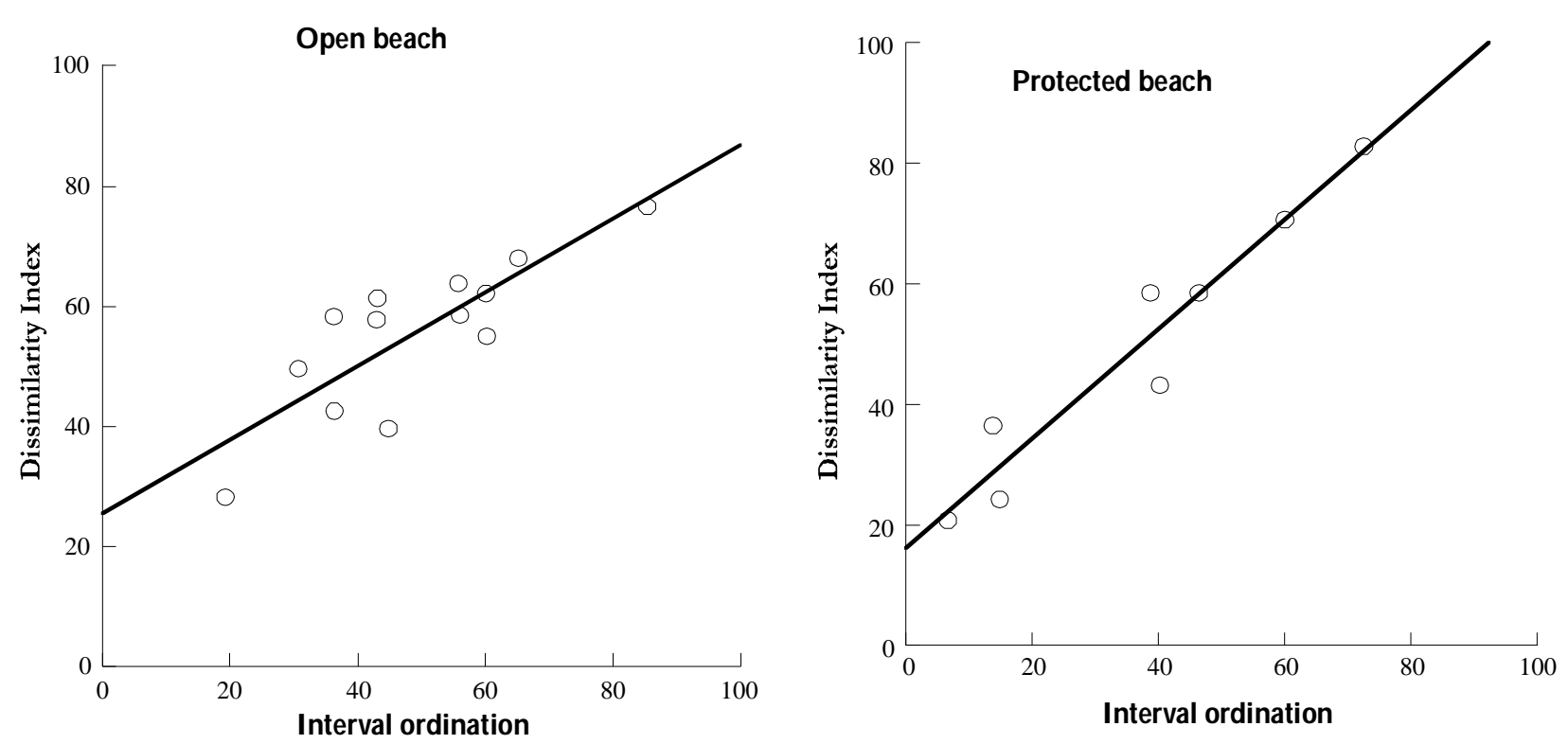

Figure 5. Relationship of interval ordination to the Dissimilarity Index of Echinoidea community at the coastal area of TomiaIsland, Indonesia
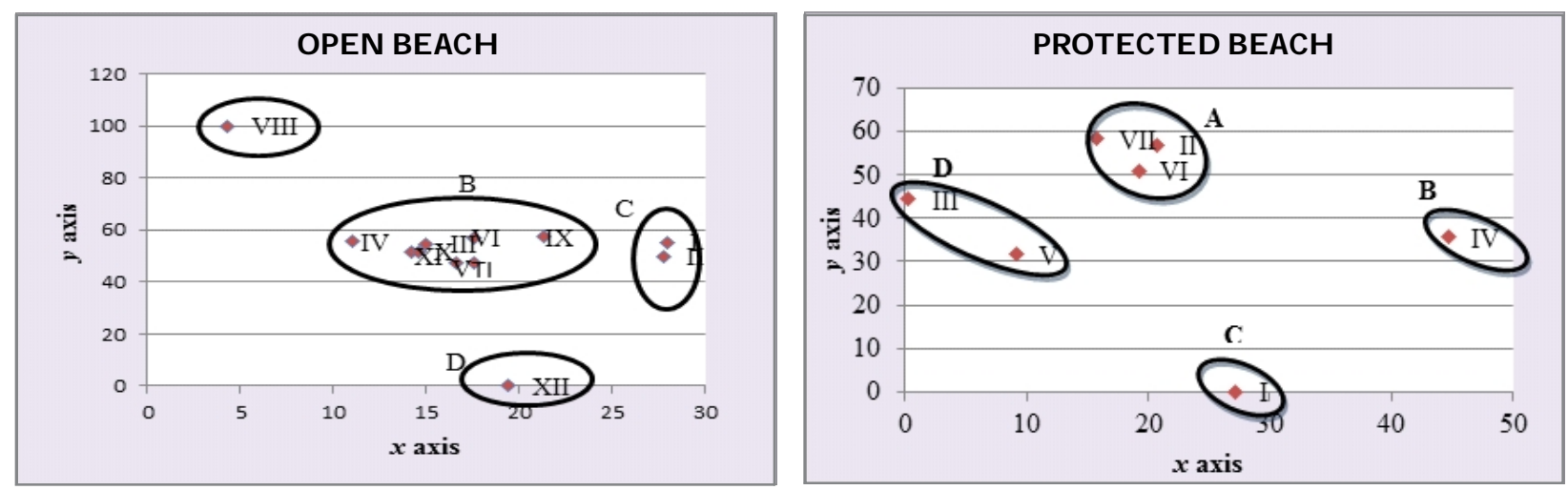

Figure 6. Ordination pattern of Asteroidea community at open beach (left) and protected beach (right) in the coastal area of Tomia Island, Wakato bi Marine National Park, Indonesia

important structuring factor in community similarity, which would result in assemblages of sites which are close together being more similar than assemblages of those which are further apart. Many previous studies revealed that distance between sites can be a function of differences in spatially explicit environmental variables (Borcard \&al. 1992; Harrison \&al. 1992; O hmann \& Spies 1998). The present result clearly found a significant association between distance of sites and community similarity for Echinoids and Asteroids both at open and protected beaches, because they showed a highly significant relationship between interval ordination and dissimilarity indexes for those two taxa. Many previous studies indicated that pattern in beta diversity can differ among taxa due to community- wide differences in dispersal ability and other taxon-specific factor (Gatson 2000; Reyers \& al. 2000). Beta diversity of organisms in many taxa has been affected by not only distance between sample stands but also environmental variables (Ellingsen \& Gray 2002; Clearly \& al. 2004). In addition, Barros \& al. (2004) found that sedimentary bedforms such as ripples, sand and waves are known to affect the abundance and distribution of benthic organisms.

Biotic factors such as human disturbance might be a factor reducing the individual number, and even the species number of these benthic communities. It is known that sea urchins are frequently collected by people for consumption, which might have strong effects on their abundance and distribution. On the other hand, 

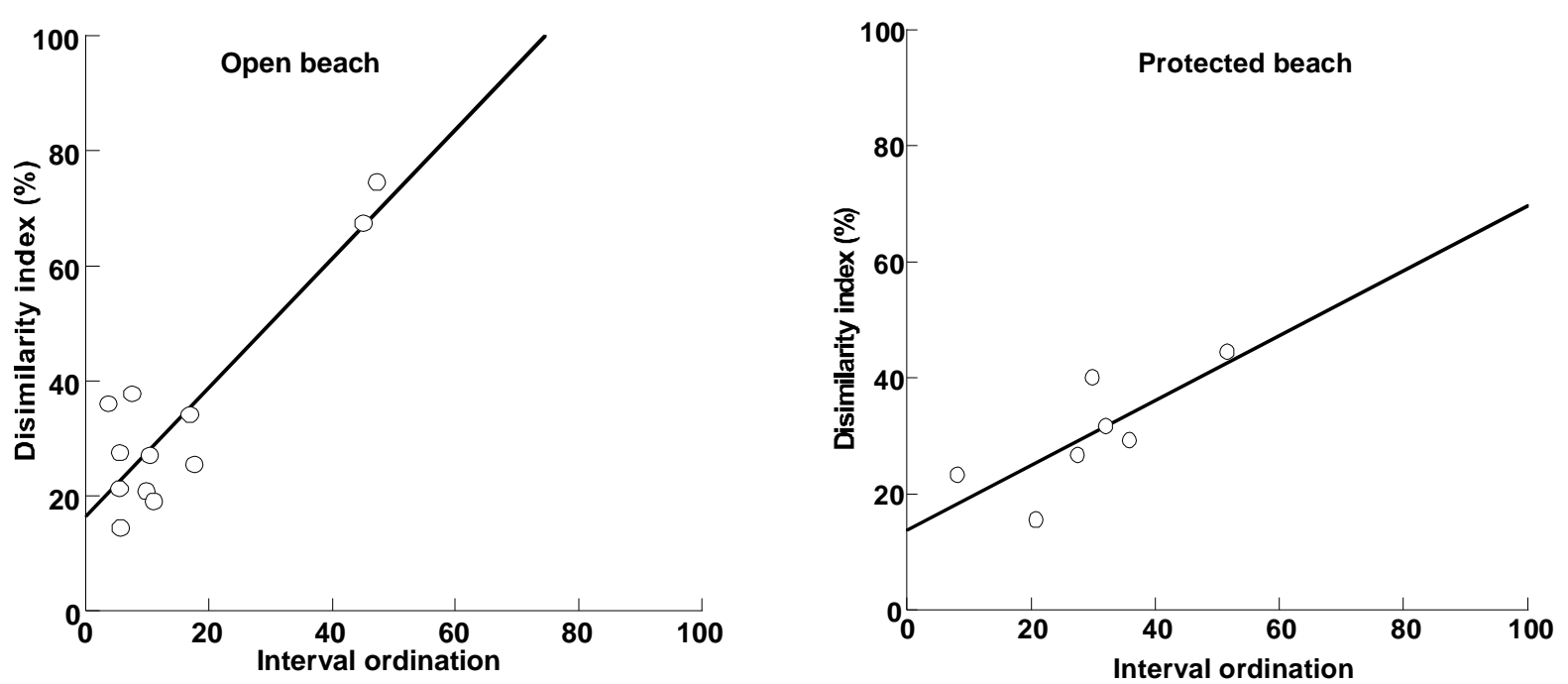

Figure 7. Relationshiop between interval ordination and disimilarity index of A steroidea community at open beach (upper) and protected beach (below) in the coastal area of the Tomia Island, Wakatobi Marine National Park, Indonesia

interactions within benthic community itself become biological control for the community stability. Meanwhile, Asteroids acts as predator for sea urchin in general, and might reduce the number of sea urchin in the coastal of Tomia Island. The association with distance itself may also be due to distance-dependent environmental variable. Several studies showed that the distribution of Echinoderms at French Polynesia beach was primarily influenced by the concentration of carbonates (Adjeroud 1997). However, Ellingsen and G ray (2002) also found in a Norwegian coastal area, that sea urchins were more restricted in their distribution than other macrobenthos, and the beta-diversity of Echinoderms had the weakest association with environmental variables of all the observed taxa.

\section{CONCLUSIONS}

Spatial patterns of the benthic community of Echinoidea and Asteroidea that inhabit the coastal area of Tomia Island, Wakatobi Marine National Park varied by habitat. Multidimensional pattern of each taxon created four groups in general, although the sites or patches in each group were quite different. The trend in beta diversity of Echinoidea and Asteroidea seemed to be associated with spatial heterogeneity because there was a significant correlation between separation of sites and community similarity of benthic community. This information is fundamental for conservation within the Wakatobi Marine National Park.

\section{ACKNOWLEDGEMENTS}

We thanked Halu Oleo University for financial support for this research. We also thanked the staff of Wakatobi Marine National Park for coopera-tion and support of our field work. We would also like to thank the students and general volunteers who had provided assistance during the field work.

\section{REFERENCES}

Adjeroud M. 1997. Factors influencing spatial patterns on coral reefs around Moorea, French Polynesia. Mar Ecol Progr Ser 159: 105-19.

Beaman RJ, Daniell JJ, Harris PT. 2005. Geology-benthos relationships on a temperate rocky bank, eastem Bass Strait, Australia. MarFresh Res 56 (7):943-58.

Barros F, Underwood AJ, Archambault P. 2004. The influence of troughs and crests of ripple marks on the structure of subtidal benthic assemblages around rocky reefs. Estuar Coast Shelf Sci 60 (4): 781-90.

Barrett N, Sanderson JC, Lawler M, Halley V, Jordan A. 2001. Mapping of inshore marine habitats in south eastern Tasmania for marine protected area planning and marine management. Technical Report. Hobart (AU): Tasmanian Aquaculture and Fisheries Institute. 
Borcard D, Legendre P, D rapeau P. 1992. Partialling out the spatial component of ecological variation. Ecology 73: $1045-55$.

Bray JR, Curtis JT.1957. An ordination of the upland forest communities of Southern Wisconsin. Ecol Monog 27:325-49.

BrowerJE, Jerrold HZ, Carl NVE. 1997. FiddandLaboratory MethoosforGeneal Ecology. New York (US): McG rawHill Higher Education.

Cleary DFR. 2003. An examination of scale of assessment, logging and ENSO-induced fires on butterfly diversity in Borneo. O ecologia 135: 313-21.

Cleary DFR, Mooers AØ, Eichhom KAO, Menken SBJ. 2004. Diversity and community composition of butterflies and odonates in an ENSO-induced fire affected habitat mosaic: a case study from East Kalimantan, Indonesia. O ikos 105:426-46.

Ellingsen KE, Gray JS. 2002. Spatial patterns of benthic diversity: is there a latitudinal gradient along the Norwegian continental shelf. J Anim Ecol 71:37389.

Gatson KJ .2000. Global patterns in biodiversity. Nature 405: 220-8.

Fortin MJ, Keitt TH, Maurer BA, Taper ML, Kaufman D M, Blackburn TM. 2005. Species' geographic ranges and distributional limits: pattern analysis and statistical issues. O ikos 108 (1): 7-17.

G ray JS. 2000. The measurement of marine species diversity, with an application to the benthic fauna of the Norwegian continental shelf. J Exp Mar Bio Ecol 250: 23-49.

Halpern BS, Walbridge S, SelkoeKA, Kappel CV, Micheli F, D'Argosa C, Bruno JF, Casey KS, Ebert C, Fox HE, Fuijita R, Heinemann D, Lenihan HS, Madin EMP, Perry MT, Selig ER, Spalding M, Steneck R, Watson R. 2008. A global map of human impact on marine ecosystems. Science 319:948-52.

Harrison S, Ross SJ, Lawton JH. 1992. Beta diversity on geographic gradients in Britain.J Anim Ecol61: 1518.

Hunt B, Vincent AC J. 2006. Scale and sustainability of marine bioprospecting for pharmaceuticals. Ambio 35(2):57-64.

Jackson JBC. 2008. Ecological extinction and evolution in the brave new ocean. Proc Nat A cad Sci 105: 1145865.

Jie H, Zhinan Z, Zishan Y, Widdows J. 2001. Differences in the benthic-pelagic particle flux (biodeposition and sediment erosion) at intertidal sites with and without clam (Ruditapes pilippinanum) cultivation in eastern China.J Exp Mar Biol Ecol261(2):245-61.

Kendall M, Jensen O, Alexander C, Field D, McFall G, Bohne R, Monaco M. 2005. Benthic mapping using sonar, video transects and an innovative approach to accuracy assessment: a characterization of bottom features in the G eorgia Bights. J Coast Res 21: 115465.

Knight TW, Morris DW. 1996. How many habitats do landscapes contain? E cology 77: 1756-64.

Koleff P, Gatson KJ, Lennon JJ. 2003. Measuring beta diversity for presence-absence data. J Animal Ecol 72(3):367-82.

Lubchenco J, Palumbi SR, Gaines SD, Andelman S. 2003. Plugging a hole in the ocean: the emerging science of marine reserves. Ecol Appl 13: S3-7.

Menge BA, Daley BA, Lubchenco J, Sanford E, Dahlhoff E, Halpin PM, Hudson G, Burnaford JL.1999. Topdown and bottom-up regulation of New Zealand rocky intertidal communities. Ecolog Monogr69(3): 297-330.

Murphy DD, Duffus DA. 1996. Conservation biology and marinebiodiversity. Conser Biol 10(2):311-2.

O hmann JL, Spies TA. 1998. Regional gradient analysis and spatial pattern of woody plant communities of O regon forests. Ecol Monog 68: 151-82.

Pauly D, Watson R, Alder J. 2005. Global trends in world fishenies: impacts on marine ecosystems and food security. Phil Trans R. Soc B 360: 5-12.

Ponder W, Hutchings P, Champman R. 2002. Overview of the Conservation of Australian Marine Invertebrates: A Report for Envirament Australia. Sydney(AU): Australian Museum.

Purvis A, Hector A .2000. Getting the measure of biodiversity. Nature 405: 212-9.

Reyers B, van Jaarsveld AS, Kruger M. 2000. Complementarity as a biodiversity indicator strategy. Proceeding of the Royal Soc London B 267: 505-13.

Roberts CM, McClean CL, Veron JEN, Hawkins JP, Allen GR, McAllister DE, Mittermeier CG, Schueler FW, Spalding M, Wells F, Vynne C, Werner TB. 2002. Marine biodiversity hotspots and conservation priorities for tropical reefs. Science 295: 1280-4.

Ross PM, Thrush SF, Montgomery JC, Walker JW, Parsons D M. 2007. Habitat complexity and predation risk determine juvenile snapper (Pagus auratus) and goatfish (Upeneidthys lineatus) behaviour and distribution. Mar Freshwater Res58(12): 1144-51.

Shirai S. 1977. Ecologial Engdopedia of TheMarineAnimalsof TheRyukyusIdand. O kinawa(JP): Shinsei To sho

Tuomisto H, Ruokolainen K, Yli-Halla M.2003. Dispersal, environment, and floristic variation of Western Amazonian forests. Science 299: 241-4.

Whittaker RH.1960. Vegetation of the Siskiyou Mountains, O regon and California. Ecol Monog 30:279-338. 